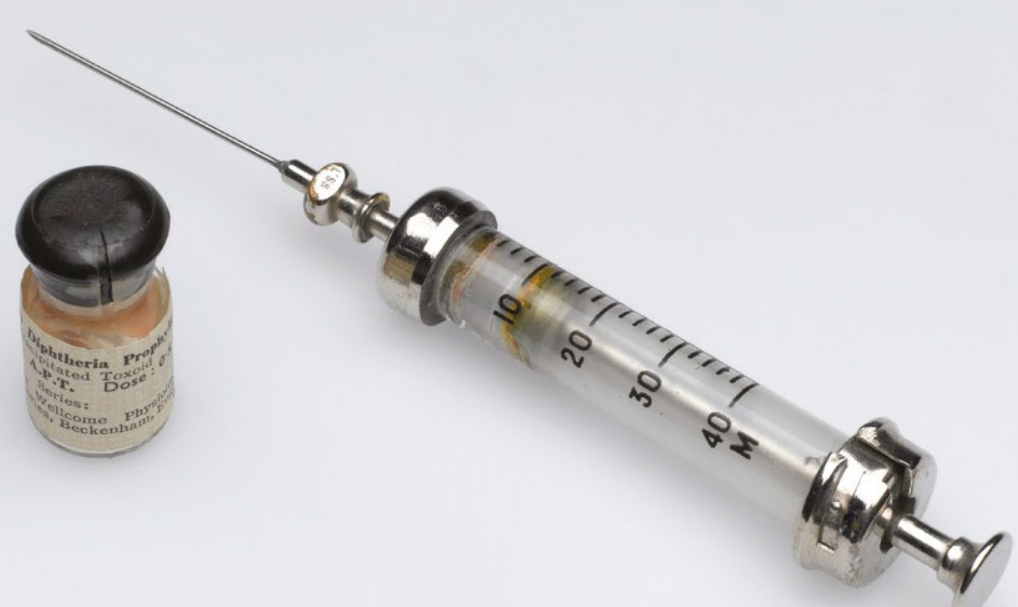

Gareth Millward Vaccinating Britain Mass vaccination and the public since the Second World War 


\section{Vaccinating Britain}

\section{MANCHESTER 1824}

Manchester University Press 


\section{S) HN}

\section{SOCIAL HISTORIES OF MEDICINE}

Series editors: David Cantor and Keir Waddington

Social Histories of Medicine is concerned with all aspects of health, illness and medicine, from prehistory to the present, in every part of the world. The series covers the circumstances that promote health or illness, the ways in which people experience and explain such conditions, and what, practically, they do about them. Practitioners of all approaches to health and healing come within its scope, as do their ideas, beliefs, and practices, and the social, economic and cultural contexts in which they operate. Methodologically, the series welcomes relevant studies in social, economic, cultural, and intellectual history, as well as approaches derived from other disciplines in the arts, sciences, social sciences and humanities. The series is a collaboration between Manchester University Press and the Society for the Social History of Medicine.

Previously published

The metamorphosis of autism: A history of child development in Britain Bonnie Evans

Payment and philanthropy in British healthcare, 1918-48 George Campbell Gosling

The politics of vaccination: A global history Edited by Christine Holmberg, Stuart Blume and Paul Greenough

Leprosy and colonialism: Suriname under Dutch rule, 1750-1950 Stephen Snelders

Medical misadventure in an age of professionalization, 1780-1890 Alannah Tomkins

Conserving health in early modern culture: Bodies and environments in Italy and England Edited by Sandra Cavallo and Tessa Storey

Migrant architects of the NHS: South Asian doctors and the reinvention of British general practice (1940s-1980s) Julian M. Simpson

Mediterranean quarantines, 1750-1914: Space, identity and power Edited by John Chircop and Francisco Javier Martínez

Sickness, medical welfare and the English poor, 1750-1834 Steven King

Medical societies and scientific culture in nineteenth-century Belgium Joris Vandendriessche

Managing diabetes, managing medicine: Chronic disease and clinical bureaucracy in post-war Britain Martin D, Moore 


\section{Vaccinating Britain}

\section{Mass vaccination and the public since the Second World War}

Gareth Millward

Manchester University Press 


\section{Copyright (C) Gareth Millward 2019}

The right of Gareth Millward to be identified as the author of this work has been asserted by him in accordance with the Copyright, Designs and Patents Act 1988.

This electronic version has been made freely available under a Creative Commons (CC-BYNC-ND) licence, thanks to the support of the Wellcome Trust, which permits non-commercial use, distribution and reproduction provided the author(s) and Manchester University Press are fully cited and no modifications or adaptations are made. Details of the licence can be viewed at https://creativecommons.org/licenses/by-nc-nd/4.0/

Published by Manchester University Press

Altrincham Street, Manchester M1 7JA

www.manchesteruniversitypress.co.uk

British Library Cataloguing-in-Publication Data

A catalogue record for this book is available from the British Library

ISBN 9781526126757 hardback

ISBN 9781526126764 open access

First published 2019

The publisher has no responsibility for the persistence or accuracy of URLs for any external or third-party internet websites referred to in this book, and does not guarantee that any content on such websites is, or will remain, accurate or appropriate.

Typeset

by Toppan Best-set Premedia Limited 